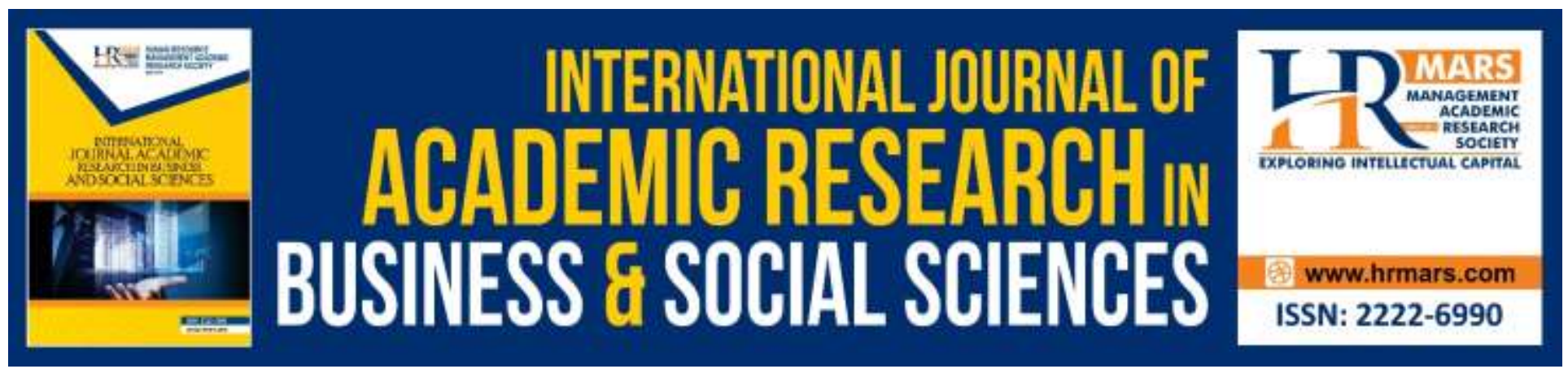

\title{
Modern Day Leadership and Sustainability of Private Secondary Schools in ARUA Municipality, Uganda
}

\author{
Olema Hamiza, Takwi Mbah Francis
}

To Link this Article: http://dx.doi.org/10.6007/IJARBSS/v10-i3/7063

DOI:10.6007/IJARBSS/v10-i3/7063

Received: 03 February 2020, Revised: 27 February 2020, Accepted: 12 March 2020

Published Online: 21 March 2020

In-Text Citation: (Hamiza \& Francis, 2020)

To Cite this Article: Hamiza, O., \& Francis, T. M. (2020). Modern Day Leadership and Sustainability of Private Secondary Schools in ARUA Municipality, Uganda. International Journal of Academic Research in Business and Social Sciences, 10(3), 470-487.

Copyright: (c) 2020 The Author(s)

Published by Human Resource Management Academic Research Society (www.hrmars.com)

This article is published under the Creative Commons Attribution (CC BY 4.0) license. Anyone may reproduce, distribute, translate and create derivative works of this article (for both commercial and non-commercial purposes), subject to full attribution to the original publication and authors. The full terms of this license may be seen at: http://creativecommons.org/licences/by/4.0/legalcode

Vol. 10, No. 3, 2020, Pg. 470 - 487

http://hrmars.com/index.php/pages/detail/IJARBSS

JOURNAL HOMEPAGE

Full Terms \& Conditions of access and use can be found at http://hrmars.com/index.php/pages/detail/publication-ethics 


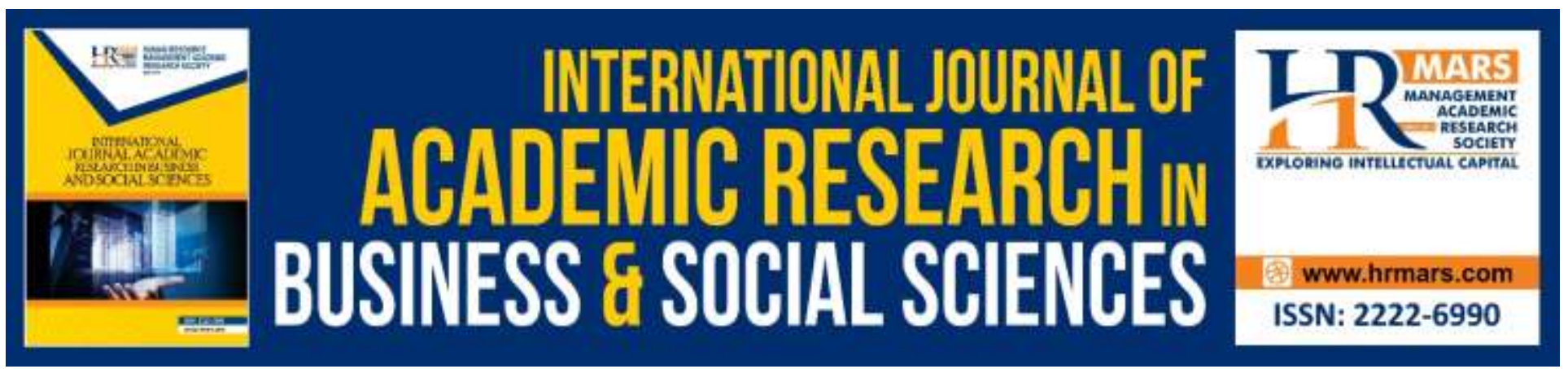

\title{
Modern Day Leadership and Sustainability of Private Secondary Schools in ARUA Municipality, Uganda
}

\author{
Olema Hamiza \\ ICT University USA, Cameroon Campus, Cameroon \\ Email: Olema.hamiza@ictuniversity.org \\ Takwi Mbah Francis \\ Ph.D, ICT University USA, Cameroon Campus, Cameroon \\ Email: frankmbah@yahoo.com
}

\begin{abstract}
This study focused on the relationship between modern day leadership and sustainability of private secondary schools in Arua Municipality, Uganda. The research axiology is value free and the approach is deductive. Data was sourced using structured questionnaire survey consisting of 7 private secondary schools registered with the ministry of education and sports. Research outcomes revealed that modern day leadership is a precursor of sustainability of private secondary schools. A crosssectional approach was undertaken. This approach prohibits studying the sequential aspects of school sustainability. The data collection instrument used was a standardized questionnaire and quantitative in nature. The use of qualitative studies with in-depth interviews could have given more insights.
\end{abstract}

The practical effects of this study are that: school administrators should be trained on visionary leadership, knowledge, skills and experiences required of a modern leader, enthusiasm and follower motivation to consequently improve productivity and performance. No known scholarly presentations on the effects of modern day leadership on sustainability of private secondary schools exists in Arua Municipality. This study is therefore of momentous contribution in this area of research. Keywords: Visionary Leadership, Knowledge, Enthusiasm, Encouragement, Sustainability, Uganda.

\section{Introduction}

Following the decision of the government of Uganda to liberalize the education sector in 1993, to allow for private actors to supplement government efforts to provide quality and affordable education, thousands of private secondary schools have been set up by private investors all over the country. Currently, $66 \%$ of schools at secondary level are private. The term 'private school' is used with varying meanings in the literature and in the policy debate (Bangay, 2007; Ashley, 2009, 2013; 
Kitaev, 1999; Lewis and Patrinos, 2012; Moran, 2006; Rose, 2006; Srivastava, 2013). This study adopted as the key factor defining 'private schools' that they are dependent on user fees to cover all or part of their operational and development costs and are managed largely independently of the state, and are owned and/or founded independently of the state. Thus, the distinctiveness of private schools is that they have to follow the market to attract and retain students in order to be financially viable. Private secondary schools have been associated with various benefits such as affordability, enriched academic opportunities, smaller classes, parental involvement, dedicated teachers, conducive learning environment and ample resources. Despite the innumerable benefits and the influx of private secondary schools in Uganda, private secondary schools in Arua Municipality in Uganda are struggling to survive and continue in operation. For example, Alliance global college that was established in 2004 is staggering, Havana secondary school that started in 2015 has collapsed. Jeden memorial secondary school established in 2015 is struggling to survive, Arua Academy secondary school that had over 1000 students in the late 1990s is left with less than 100 students, and Everest secondary school that commenced operations in 2014 and by 2015 had a total number of 800 students has collapsed within three years (Arua Municipal Education status report, 2018).

Extensive research has been conducted on private secondary schools. For instance, Ssali (2009) explored challenges/dilemmas of private secondary school management and leadership in Uganda. Boonla (2013) studied the relationship between the Leadership Style and School Effectiveness in School under the office of Secondary Education. Naluwemba et al., 2015; examined school heads' leadership traits and learners' academic Attainment in Uganda's High Schools. Purna (2011) studied leadership and school principals. Pont et al., (2008) explored policy and practice of improving school leadership. Day and Aslam (2014) deliberated on the role and impact of private schools in developing countries and Amanchokwu (2014) studied Management of Secondary Education for Sustainable Living in a Period of Security Challenges in Nigeria. . It is however particularly relevant to observe that none of these studies specifically sought to examine the effect of modern day leadership on sustainability of private secondary schools.

\section{Problem Statement}

The survival and sustainability of private secondary schools in Arua Municipality in particular, and Uganda as whole has become under serious public and scholarly scrutiny given many private secondary schools are struggling to grow with very disturbing survival rates. Fewer than half of all new private secondary schools usually remain in active operation only after five years of creation (UBOS, 2018). Furthermore, the Principal Education Officer of Arua Municipality wept in desperation that 2 in every 3 private secondary school start-ups in the Municipality cannot live to celebrate their first anniversary. Thus, survival and sustainability is a major problem among private secondary schools. This is unacceptable and cannot be tolerated; otherwise the private education sector will become stagnant and slowly cease to exist and this will frustrate the government's effort to reduce illiteracy rates in the country. This could be attributed to lack of modern day leadership. Given this state of affairs, the need to establish the effect of modern day leadership on sustainability of private secondary schools is called for in Arua Municipality. 
INTERNATIONAL JOURNAL OF ACADEMIC RESEARCH IN BUSINESS AND SOCIAL SCIENCES

Vol. 10, No. 3, March, 2020, E-ISSN: 2222-6990 (C) 2020 HRMARS

\section{Research Questions}

1.1.1 What embodies modern day leadership?

1.1.2 Is there a relationship between modern day leadership and sustainability of private secondary schools?

1.1.3 What is the effect of modern day leadership on sustainability of private secondary schools?

\section{Research Objectives}

- To understand modern day leadership.

- To establish the relationship between modern day leadership and sustainability of private secondary schools.

- To find out the effect of modern day leadership on sustainability of private secondary schools.

\section{Justification of the Study}

This study will have both theoretical and practical contributions. Theoretically, the study adds on to the knowledge on modern day leadership. Scholars and academicians will also find this study an invaluable source of reference material for future studies in the area as well as for discussions in the field of leadership. Practically, the study will be invaluable to private investors and or private secondary school leaders can use the findings of the study to enhance school investment sustainability. It provides important insights that allow technocrats such as the Principal Education Officers to better understand private secondary school survival and sustainability issues.

\section{Literature Review \\ Conceptual literature}

Leadership is a concept that has been sought and discussed for a very long time. Leadership can be defined in different ways that it is hard to come up with a single working definition. Leadership has different meanings to various authors. Leadership is not just a person or group of people in a high position. According to Lawal (1993) Leadership is the process of influencing others to work willingly toward an organizational goal with confidence. "Leadership is generally defined simply as the process of influencing people to direct their efforts towards achievement of some particular goal or goals". According to Koontz et al. (1978), "Leadership is generally defined simply as the art of influencing people so that they will strive willingly towards the achievement of group goals". This concept can be enlarging to include not only willingness to work but with zeal and confidence.

Nwanchuckwu (1998) defines leadership simply as an act that involves influencing others to act toward the attainment of a goal". Ubeku (1975) defines leadership as the act of motivating or causing people to perform certain task intended to achieve specified objectives. Leadership is the act of making things happen rather than letting things happen. This the leader does by exerting both intrinsic and extrinsic influences on the group. According to Koontz et al., (1978) "leadership is generally defined simply as the art of influencing people so that they will strive willingly towards the achievement of group goals". "This concept can be seen to include not only willingness to work but with zeal and confidence. Sikula (1996), sees "leadership simply as an act that involves influencing others to act toward the attainment of a goal". According to Akpala (1982) "leadership has been 
INTERNATIONAL JOURNAL OF ACADEMIC RESEARCH IN BUSINESS AND SOCIAL SCIENCES

Vol. 10, No. 3, March, 2020, E-ISSN: 2222-6990 (C) 2020 HRMARS

defined in terms of functions performance by executives as 'individuals and as a group". This concept clarify that the responsibility of the superior is to direct behaviour into channels that promote the achievement of organization and departmental goals.

\section{Definition of Modern Day Leadership}

Leadership continually incorporates new ideas and embodies differing styles, ambitions and goals. Today people envision leadership as a necessary part of business. With global markets and the everchanging wants and needs of consumers, the old methods of business are no longer sufficient (Forrest, 2011). The study of leaders and leadership has a long history. As Sarros and Woodmman (1993) have observed "leadership have existed for as long as mankind has been civilized. For almost as long, Taoism emphasized leadership qualities in terms of guiding and nurturing followers. However, Leadership styles that were practiced in the traditional hierarchies and that relied on authoritarian controls are seldom applicable to the changing workforce of the 21st century. Instead new styles of leadership are needed in contemporary organizations, ones that could improve trust, creativity and motivation amongst their followers. Leadership is not an easy task for a culturally diverse workforce.

According to forrest (2011) modern Leadership consist of Vision, Knowledge, Enthusiasm Experience and people's need for Encouragement. A Vision or dream can give direction to a company or a department within a company. Vision can define the growth of an organization or a segment of society. Vision sets direction and even if the goal becomes slightly different it is still the destination, a striving point. Knowledge is a tool that helps validate a leader to those who are being led. With knowledge, a leader can direct, supervise and assist. Enthusiasm/drive; many people who have studied leadership point to enthusiasm as a very useful tool of leadership. The author feels that enthusiasm in itself can be limiting and has chosen to refer to this tool of leadership as drive. Drive, in the author's opinion, takes enthusiasm into account and adds the element of movement to the concept. A leader has a responsibility to keep his or her team focused. Encouragement; is a tool that lets a leader combine enthusiasm with the responsibility of guiding and succeed in not alienating the people that they are leading. Encouragement can take on many forms and is part of the enthusiastic attitude needed to use the leadership drive tool. Many have mistaken reward as an encouragement of some kind and use rewards whether monetarily or non-monetarily as encouragement. In many situations rewards are not the appropriate form of encouragement, and if offered some being led may be offended. 
INTERNATIONAL JOURNAL OF ACADEMIC RESEARCH IN BUSINESS AND SOCIAL SCIENCES

Vol. 10, No. 3, March, 2020, E-ISSN: 2222-6990 (C) 2020 HRMARS

\section{Comparison of Modern and Traditional/Historical Leadership}

Leadership today has changed significantly over what was considered leadership forty, even twenty years ago as shown in table 1.

Table 1 Difference between modern day leadership and traditional leadership

\begin{tabular}{|r|r|}
\hline Modern Day Leadership & Traditional/Historical Leadership \\
\hline Have long-terms vision & Have short-term vision \\
\hline Have knowledge of leadership & Lean on other people's knowledge and support \\
\hline Are enthusiastic & Often try to force enthusiasm \\
\hline Have experience in leadership & Have limited experience \\
\hline Owe responsibility to the followers & Do what is necessary for themselves \\
\hline
\end{tabular}

\section{Sustainability of School}

Sustainability is a concept that should originate from the organization itself with suggestions and guidance from entities external to the organization. It reflects the property of a program to benefit from the currently available resources and continue to grow in time. Sustainability is defined as the propensity of an object or a program or institution to continue and to grow in time (Rani, 2013). Sustainability of school therefore involves continued school existence, shared purpose of the schooling, student achievement, teacher well-being and effectiveness, student achievement, steady academic performance record and increased student enrollment (Hall-Kenyon, 2014; Jimenez, 2017; Lunby, 2013; Smit,h 2017; \& Bulut, 2015).

\section{Conceptual Model}

The conceptual framework relates modern day leadership to sustainability of private secondary schools. The dependent variable is sustainability of private secondary schools, while the independent variable is modern day leadership conceptualized as Vision, Knowledge/Experience, Enthusiasm, and Encouragement.as depicted in figure 1: 
INTERNATIONAL JOURNAL OF ACADEMIC RESEARCH IN BUSINESS AND SOCIAL SCIENCES Vol. 10, No. 3, March, 2020, E-ISSN: 2222-6990 @ 2020 HRMARS

Independent Variable

Dependent Variable

\section{Modern Day Leadership}

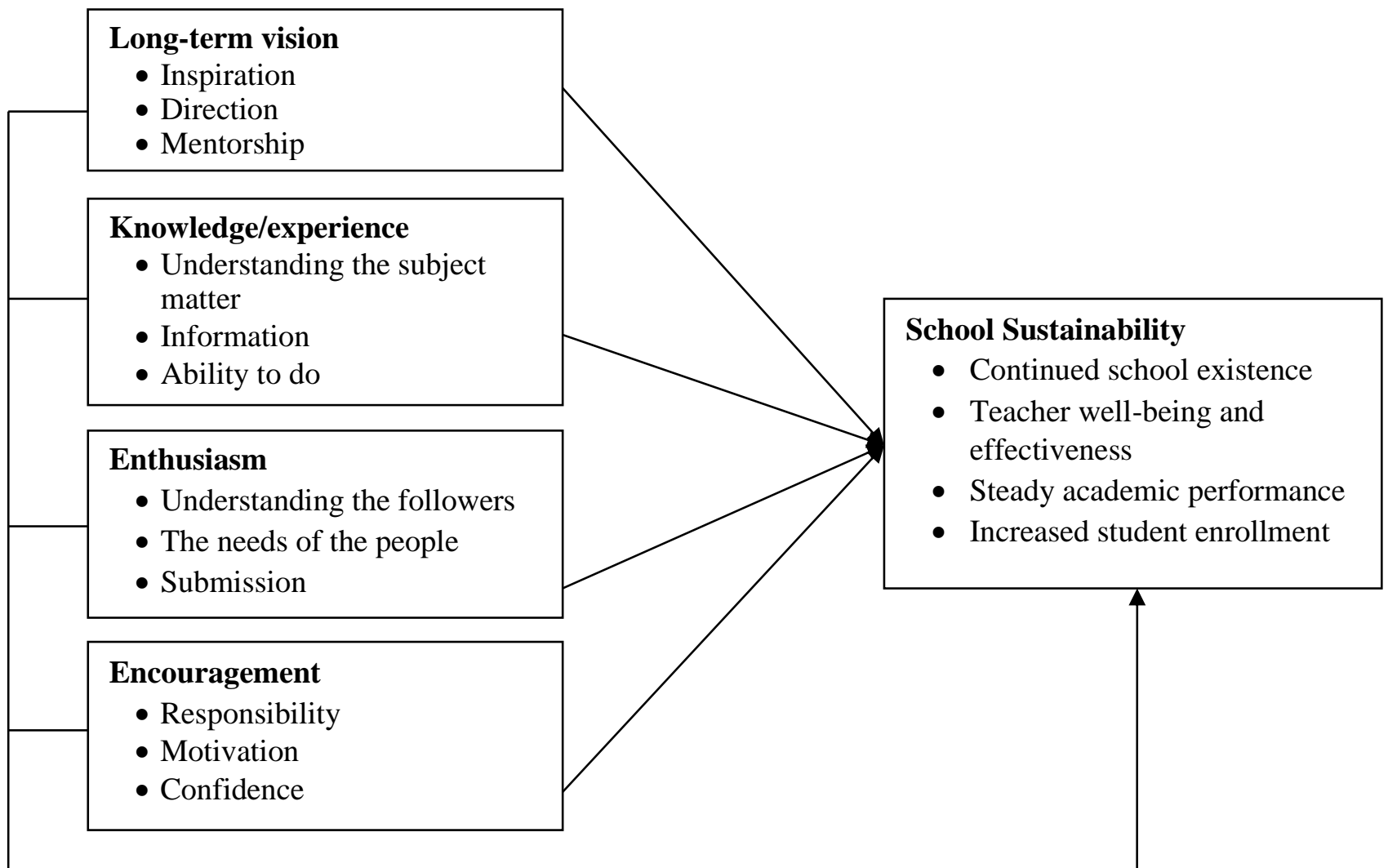

Figure 1: Effect of Modern Day Leadership on School Sustainability

Source: Adopted and modified from Forrest (2011); Hall-Kenyon (2014); Jimenez (2017); Lunby (2013); Smith (2017); and Bulut (2015).

\section{Theoretical Framework}

Leadership has been grounded in many theories, some of them complementary and others are contradictory, but for the purposes of this study, the following theories are analyzed: The Behavioral theory of leadership (Blake, 1940), contingency leadership theory (Fiedler, 1967) and path-goal theory (House, 1971).

Behavioral theory of leadership came about as a result of the Ohio state studies in the 1940s. It classified two dimensions along which leadership behavior can be identified and compared: initiating structures and consideration. A leader who shows a high degree of initiating structures is concerned with detailing task requirements, clarifying and emphasizing standards of work assignments and schedules. A leader who shows a high degree of consideration is sensitive to employees' ideas, emphasizes trust and seeks to communicate. This theory suggests that leaders who can choose and adopt both initiating structures and consideration style of management appropriate to the situational requirements will be more successful. A major research by Blake and Mouton (1964) found that most managers agreed that ideal leadership style is the integration of relationship and task orientation. However, when the managers have been asked to describe their actual style, the practice was more 
INTERNATIONAL JOURNAL OF ACADEMIC RESEARCH IN BUSINESS AND SOCIAL SCIENCES Vol. 10, No. 3, March, 2020, E-ISSN: 2222-6990 @ 2020 HRMARS

task than relationship oriented. Similarly, Weiss (1996) argued that based on current literature, there is no conclusive evidence to support the notion that a particular combination of initiating structure and consideration will result in optimum groups' performance.

Another important theory is the contingency leadership theory of Fiedler (1967). The theorist postulated that leadership style depends on three contingency variables: task structure, leadermember relations and the leader's position power. Task structure refers to extent the task is routine or non-routine. Routine task has a well-defined goals and procedures. The outcomes are verifiable and the means of performing the work is specific. Non-routine tasks have the opposite characteristics. Leader-member relations refer to the extent to which a group accepts a leader. Acceptance leads to commitment and loyalty, unacceptance leads to friction and tension. Leader position power refers to the extent a leader can hire, fire, reward and discipline subordinates. Organizations, Fielder claims, should match tasks and work environments with an individual's leadership style to ensure high group performance. Whilst Fielder's theory has been tested, questions remain over the cross-cultural reliability of the theory and of the selection and measurement of the major variables (Weiss, 1996).

Another theory of relevance to this study is the path-goal theory. The path-goal theory of House (1971) argues that leaders are effective if they can clarify goals for subordinates and assist them in attaining these goals. The leader can assist by providing training, coaching and guidance and by removing obstacles to goal attainment. House proposes and defines four leadership styles which he beliefs could be adopted by leaders, depending on the situations: Directive; leaders inform of what to do and when to do it. This is a telling style. Supportive; leaders are friendly with followers and show them what to do. This is sharing style. Participative; leaders are friendly with followers and solicit their ideas and suggestions. This is a consultative style. Achievement oriented; leaders set challenging goals and show confidence in employee performance. This is delegating style. However, research findings regarding the validity of the path-goal theory are mixed (Ful and Wendler, 1983). This is because this theory was originally developed in Anglo culture, in particular USA, which may not be applicable in other cultures around the world.

Table 2: Summary of theories on which the study is anchored

\begin{tabular}{|c|c|c|c|c|c|}
\hline Theory & Author & Year & Gist of the theory & Relevancy & Limitation \\
\hline BTL & $\begin{array}{r}\text { Blake } \\
\& \\
\text { Mouto } \\
\mathrm{n}\end{array}$ & 1940 & $\begin{array}{r}\text { Dimensions of } \\
\text { leadership } \\
\text { behavior }\end{array}$ & $\begin{array}{r}\text { Leader behavior } \\
\text { predicts success }\end{array}$ & $\begin{array}{l}\text { conclusive } \\
\text { evidence }\end{array}$ \\
\hline CLT & Fiedler & 1967 & $\begin{array}{r}\text { Work situations } \\
\text { vary }\end{array}$ & $\begin{array}{lr}\text { Matching leadership } \\
\text { styles } & \text { with } \\
& \text { situations } \\
\end{array}$ & $\begin{array}{l}\text { Selection and } \\
\text { measurement of } \\
\text { variables is difficult }\end{array}$ \\
\hline PGT & House & 1971 & $\begin{array}{ll}\begin{array}{l}\text { Clarification of } \\
\text { goals }\end{array} & \text { to } \\
\text { subordinates }\end{array}$ & $\begin{array}{lr}\text { Goal } & \text { oriented } \\
\text { leadership } & \text { and } \\
\text { culture }\end{array}$ & $\begin{array}{r}\text { May not apply across } \\
\text { cultures }\end{array}$ \\
\hline
\end{tabular}


INTERNATIONAL JOURNAL OF ACADEMIC RESEARCH IN BUSINESS AND SOCIAL SCIENCES

Vol. 10, No. 3, March, 2020, E-ISSN: 2222-6990 @ 2020 HRMARS

\section{Empirical Literature and Hypotheses}

\section{Visionary leadership and Sustainability of Private Secondary Schools}

The first tool that is often referred to as the most important skill or tool that a leader in today's society must have is that of Vision. Vision is often regarded as a management tool for corporate leaders. It is widely regarded as important in leadership, strategy implementation, and change (Sooksan, 2006). Vision is frequently confused with, or even deliberately combined with, terms like mission, goals, strategy, values and organizational philosophy (Levin, 2000). Despite the often-diverging terms used for vision, many definitions share common characteristics, including: Vision is about a desirable future (Collins and Lazier, 1992). It is a process of inducing others to act toward a common Goal (Bennis, 1990). Vision is a mental image of a possible and desirable future of the organization (Maxey, 2000) Kouzes takes it as "an ideal and unique image of future for the common good" (Kouzes and Posner, 2007). A Vision or dream can give direction to a company or a department within a company. A Vision can define the growth of an organization or a segment of society. Vision sets direction and even if the goal becomes slightly different it is still the destination, a striving point

Visionary leadership is an imperative for shaping a group of followers into teams and gradually develops them as high performance work groups that serve as competitive advantage to business. Visionary leaders are successful at manifesting their vision based leadership on an inspirational, positive picture of the future, as well as a clear sense of the path to reach the goals. Great leaders give real thought to the values, ideas and activities that they are most passionate about and pursue. They achieve them only by setting realistic, demanding goals and then going after them relentlessly, with the help of other talented men and women who are equally committed and engaged. The effective visionary leadership has to customize and concentrate on situational basis and necessity of change. The effective leadership can be seen only if it sustains till it achieves goals set. Visionary leaders are noted for their situational and transformational attitude and approach which compels followers to transform the old mental maps to create the culture of innovation. The visionary leader must create his or her concept of what the organization can accomplish. They create innovative strategies for actualizing their vision.

In 21st century, a pro-active involvement of individuals is required to lead the organizations. An enterprise needs good, if not the best visionary leaders to stay and sustain in the competition. Companies must carefully harness the leadership strategies and build an organizational culture that fosters growth of talented workforce (Krishna, 2012). A good vision must not only inspire and engage followers but it must also make the followers believe that it achievable by them collectively. Most inspiring visions have a common theme of dealing with change by making people work together towards ideal goal (Sashkin, 1988). An effective visionary leader should have a vision with good implementation strategy that inspires the followers to engage enthusiastically. To understand the crucial difference between a vision with good intentions, and a vision good implementation, we are here analyzing the traits of visionary leaders that inspire the followers to enthusiastically engage themselves in pursuit of its implementation. According to Carneiro (2008), to survive, excel and be sustainable in this age of global competition, organizations have come to realize the need of managers/leadership with vision and think about strategies of turning the vision into reality. Without 
INTERNATIONAL JOURNAL OF ACADEMIC RESEARCH IN BUSINESS AND SOCIAL SCIENCES

Vol. 10, No. 3, March, 2020, E-ISSN: 2222-6990 @ 2020 HRMARS

individuals imparting a vision to those around them we would not have the communities that exist today (Wazler, 2017)

H1. Visionary leadership positively influences sustainability of private secondary schools

\section{Leadership Knowledge and Sustainability of Private Secondary Schools}

Knowledge is a tool that helps validate a leader to those who are being led. With knowledge, a leader can direct, supervise and assist. Without knowledge a leader is often limited to encouraging and providing the overall goal. Knowledge is an extremely effective tool for a leader. Sometimes however using the impression of a lack of knowledge can also improve effective leading ability (Cully, 2016). Knowledge is the appropriate collection of information, such that its intent is to be useful (Ackoff, 1989). It pertains to information given meaning and integrated with other contents of understanding (Bates, 2005). Davenport and Prusak (1998) defined knowledge as "a fluid mix of framed experience, contextual information, values and expert insight that provides a framework for evaluating and incorporating new experiences and information." The knowledge management literature has shown that knowledge management plays an important role in the performance of organizations (Alavi and Leidner, 2001; Cameron, 2004; Sabherwal and Becerra-Fernandez, 2003; Srisa-ard, 2006; Zack, 1999).

Knowledge in two distinct areas can impact a leader. First is the leader's actual knowledge of how to lead. If a well-seasoned leader undertakes to lead they understand how to impart a vision, and they realize that there are certain things that they may need to learn before working with a group, many of whom could be experts in a certain field. The second area a leader will need at least a basic level of knowledge is the subject matter in which they are leading. Without some subject matter knowledge the people led will not be as accountable to the leader, because there is less accountability. In addition if they know that the leader does not have any subject matter knowledge it is possible followers may not respect the leader. The best leaders are equipped with leadership knowledge, and then seek out topical knowledge for the specific area in which they will lead (Forrest, 2011). The value of knowledge is accepted by most of society in modern era. Leaders that have the knowledge to direct teams and to develop more leaders will find their organizations able to adapt more quickly to the changes in the age of information.

Pearce wrote: "The end of the modern era has brought with it a well-documented confusion of values and a substantial shake-up in fundamental beliefs. Much of the world's accumulation of the information is universally available, and as a result, the people with the most knowledge no longer have the same leverage to gain leadership positions. In fact, the seemingly unlimited availability of information offers more confusion, more possibilities, and the average person is left groping for certainty" (Pearce, 1995).

Leaders have a significant position of influence within their organizations. Knowledge leadership has increasingly been recognized as an essential element for organizations to enhance growth and sustainability. From another point of view, the behavioral and contingency approaches suggested that leader behavior should involve information search and acquisition and information use which are critical to performance (Fleishman et al., 1991). In addition, Vroom and Jago (1988) contended that information and knowledge requirements of situations are key contingencies that influence 
leader behavior. The behavior of the leaders in facilitating the existence and availability of required information and knowledge can have a positive effect on organizational effectiveness (Lakshman, 2007). Most public management scholars agree that leadership in public organizations to some extent requires distinctive skills and knowledge (Rainey, 2014: 364), and some studies have shown that the impact of leadership depends on context factors (Lim \& Ployhart, 2004; Wofford et al., 2001; Avolio et al., 2009). In terms of theory, however, there is still need for more work on what exactly constitutes public leadership (Vogel \& Masal, 2014: 15). In order for companies to succeed in business, knowledge leadership and knowledge management capabilities are two of the important components that companies must possess (Earl and Scott, 1999; Liebowitz, 2000; Saint-Onge, 1999). Companies worldwide have responded by creating or re-evaluating their knowledge leadership development programs and knowledge management initiatives (Davenport and Prusak, 1998; Malhotra, 2000). Knowledge leadership is an essential element for organizations (Brown and Duguid, 2000). It is an important business development activity (KPMG, 2000). The role of knowledge leadership is to promote a positive cultural orientation toward knowledge acquisition and knowledge sharing; one that values continuous learning, where experience, expertise, and innovation supersede hierarchy (Davenport et al., 1998).

H2. Leadership knowledge is positively related to sustainability of private secondary schools

\section{Leader Enthusiasm and Sustainability of Private Secondary Schools}

The notion of enthusiasm may seem far removed from the attributes that a leader needs in order to succeed, but it is an important part of being an effective modern leader. The speed of the changes in the workplace presents unprecedented challenges for secondary schools currently. The central task of a leader is to produce results with high levels of expertise and to support life-long growth. Enthusiastic experts are needed in today's workplaces (Zhu \& Engels, 2014).

The word 'enthusiasm' derives from the Greek meaning 'God (entheo) inside (iasm)'. While Sanders and Gosenpud (1986, p. 52) state that 'enthusiastic leadership' means simulating, animated, energetic and mobile - it suggested that the notion extends beyond mere kinetics and includes a love of one's discipline, closeness, affection, fear, hope, accompaniment, confidence, observance certainty and being more insightful (Ballantyne et al., 1999). The waning of leaders' enthusiasm should be of concern to everyone in the tertiary sector, as a leader's enthusiasm towards the followers has been linked to promoting engagement and positive outcomes (Evans, 2007), which is beneficial for the institution and the sector overall. Given the demands of the contemporary education sector, leaders more than ever need enthusiasm to face the challenges of their responsibilities. Enthusiasm is equivalent for excitement (Sajjadi, 2014).

The effects of enthusiasm have been studied in the work of teachers at various education levels (e.g., Keller et al., 2014). In sum, teacher enthusiasm has a positive influence on student learning, performance, and motivation (Keller, Neumann, \& Fisher, 2013; Kunter et al., 2013; Patrick et al., 2000), and on teaching quality (Kunter et al., 2011; 2013). An enthusiastic leader promotes enthusiasm in his followers (Frenzel, 2008; Frenzel et al., 2009). Enthusiasm has been noted to 
INTERNATIONAL JOURNAL OF ACADEMIC RESEARCH IN BUSINESS AND SOCIAL SCIENCES Vol. 10, No. 3, March, 2020, E-ISSN: 2222-6990 @ 2020 HRMARS

increase productivity and quality at work. In teachers' work, this has a connection to student learning and motivation, as well as teaching quality.

Leaders, when they are not in the best of moods, tired or any one of a number of different factors, often try to force enthusiasm. Unfortunately many leaders today are enthusiastic about the task and not the people (Patrick, Hisley, \& Kempler, 2000). Even though this is beneficial it does not increase followers' enthusiasm if other things need addressing. Overall, most leaders do not know how to use enthusiasm. Ideally leaders should spend time learning people and understanding when and where to encourage and be enthusiastic. Many leaders today think that submission means they are not a leader, but to be a leader you need to know your mission, goal and you must submit to those in authority over you. In business you must submit to your boss and, if not him, then the owner or owners. If a leader is an owner then they must submit to the needs of their customers. If a leader is not submitted then they really will not be enthusiastic in the long run, or know how to deal with their followers or peers (Kunter et al., 2013).

H3: Leader enthusiasm significantly affects sustainability of private secondary schools

\section{Leader Encouragement and Sustainability of Private Secondary Schools}

Encouragement; is a tool that lets a leader combine enthusiasm with the responsibility of guiding and succeed in not alienating the people that they are leading. Sweeney (2009), an Adlerian psychotherapist, explained that "to provide encouragement is to inspire or help others, particularly toward a conviction that they can work on finding solutions and that they can cope with any predicament" .In contrast, Nikelly and Dinkmeyer (1971) defined encouragement as a non-verbal attitude that communicates esteem and worth to an individual. Dinkmeyer and Losoncy (1996) provided abroad definition that has been commonly cited by Adlerian scholars: "encouragement is the process of facilitating the development of a persons' inner resources and courage toward positive movement". Adlerian scholars have elucidated a wide range of encouragement skills, including reflective listening, use of humor, communicating faith in others, smiling, non-verbal acceptance of others, expressing genuineness, pointing out others' strengths, positive reframing, and validating others' goals (Carn \& Carns, 2006).

Therefore, in this article, we provide a narrower definition of encouragement by drawing from several Adlerian concepts, while also imposing conceptual boundaries that may help distinguish encouragement from other constructs. At its most basic level, encouragement is the expression of affirmation through language or other symbolic representations to instill courage, perseverance, confidence, inspiration, or hope in a person(s) within the context of addressing a challenging situation or realizing a potential. This article's review of the literature on encouragement will focus mainly on language-based expressions of encouragement, given that that has been the focus of most psychological empirical research on encouragement (Hwang et al., 2011

Encouragement is one of the most common ways through which individuals express support for one another (Beets, Cardinal, \& Alderman, 2010; Hwang et al., 2011; Jose \& Bellamy, 2012). Encouragement is also a prominent theme in several self-help books (Maxwell, 2008), including those 
on enhancing marital satisfaction (Rainey \& Rainey, 2010) and leadership skills (Dinkmeyer \& Eckstein, 1996). It is a motivating factor. Work motivation is a popular topic in work and organizational science. It is broadly defined as a set of energetic forces that originates both within as well as beyond an individual's being, to initiate work-related behavior, and to determine its form, direction, intensity and duration. One of the important topic about works motivation is what factor impact to work motivation. And the answer of this come from some research e.g. Rawung (2012) on her research finding that leadership has significant impact to work motivation in administration employee on university organization. Other researcher has similar finding as this research: in military organization (Wagimo \& Ancok, 2005); in university organization (Ariyani, 2011); in hospitality organization/industry (Prasastono, 2012); in public service organization (Widyanto \& Sutarno, 2011). The results of all research find that leadership has positively significant impact to work motivation.

At the most basic level, leadership theories propose that leaders can have a powerful impact on individual, group, and organizational outcomes. Further, follower motivation is thought to be a primary mechanism through which leaders exert their influence. Thus it follows that if leaders wish to improve outcomes, they should enhance the motivation of their followers (Harrell, 2008).

Work motivation is a reflection of personal attitudes and of attitudes towards group work and collaboration. Such as attitudes to every employee, motivation is also to some extent influenced by the factors of the leaders' part, especially by the leaders' wisdom (Rawung, 2012).

In discussing leadership issues, especially in relation to work motivation, the issue of leadership styles cannot be forgotten of. There are four styles of leadership, e.g (Rawung, 2012): (i) exploitive/authoritative style is very autocratic managers, has less trust to his subordinates, like exploiting subordinates, and paternalistic act, (ii) Autocratic style, where the leaders or managers that are included in this system has a hidden belief, trust in subordinates, (iii) a consultative style manager, where managers give little confidence in subordinates usually the case when he needs information, ideas or opinions of subordinates, and still want to control the decisions he makes, and (iv) participatory group style (participative group), where the manager has perfect confidence against subordinates. Based on research conducted, several experts associated work motivation induced by leaders to increased employee work.

$\mathrm{H}$ 4. Leader encouragement has a positive and significant relationship with sustainability of private secondary schools.

\section{Research Methodology}

This study used a descriptive research design. The target population was 7 private secondary schools dully registered by the ministry of education and sports, with an approximate population of 70 school leaders. A sample size of 59 administrators based on Krejicie and Morgan (1970) table for determining sample size was used. The respondents included school directors, board of directors, head teachers, director of studies, Patrons, senior women teachers and careers' masters currently managing and leading schools and have knowledge about the subject matter. 
INTERNATIONAL JOURNAL OF ACADEMIC RESEARCH IN BUSINESS AND SOCIAL SCIENCES

Vol. 10, No. 3, March, 2020, E-ISSN: 2222-6990 (C) 2020 HRMARS

Data was collected using a self-administered questionnaire anchored on a five-point Likert scale ranging from strongly disagree to strongly agree with close-ended items. Data was analyzed using descriptive and inferential statistics.

\section{Analysis and Results \\ Descriptive Statistics}

Findings revealed that most of the school leaders are male (78\%), compared to female who are the minority (22\%). Majority of the leaders are in the age bracket of $30-40$ (64\%). As regards education level of the administrators, (69\%) of the respondents are bachelor's degrees holders who are expected to be knowledgeable. (60\%) of the respondents have worked for 3-8years, contributing. The least was those who have worked for more than 15 years which contributed 18\%, indicating low levels of school sustainability.

Reliability and Validity Tests

We tested for reliability of the questionnaire using Cronbach's $\alpha$ coefficient. Cronbach (1951) requires a Cronbach's $\alpha$ coefficient of at least 0.7 and above and Cronbach's $\alpha$ values for this study were all above 0.7 and thus the instrument was reliable. Item analysis was done to check whether the items in the instrument were correct and a pre-test was carried out using focus experts to check for validity. Results from experts were 0.68 and 0.82 respectively. This showed that the instrument was very relevant and valid.

\section{Correlation Results}

The zero order correlation was used to test the relationship between modern day leadership constructs and sustainability of private secondary schools. The correlation results are displayed in table 3.

Table 3. Zero order correlation coefficients

\begin{tabular}{|l|l|l|l|l|l|}
\hline Variables & LTV & KNO & ENT & ENC & SST \\
\hline & & & & & \\
\hline LTV & 1 & & & & \\
\hline KNO & $.432^{* *}$ & 1 & & & \\
\hline ENT & .211 & .163 & 1 & & \\
\hline ENC & .334 & $.654^{*}$ & .872 & 1 & \\
\hline SST & .198 & $.501^{* *}$ & $.678^{* *}$ & $.277^{*}$ & 1 \\
\hline
\end{tabular}

* Correlation is significant at the 0.05 level $(p<0.05)$.

** Correlation is significant at the 0.01 level $(p<0.01)$.

Significant correlations between modern day leadership constructs and school sustainability were found. Specifically, the results showed a significant positive association of leader enthusiasm and school sustainability $\left(r=.678^{* *}\right)$, and leadership knowledge with school sustainability $\left(r=.501^{* *}\right)$, as were leader encouragement to school sustainability $\left(r=.277^{*}\right)$ and visionary leadership ( $\left.r=.198\right)$. The findings denote that an increase or decrease modern day leadership constructs (leader enthusiasm, 
INTERNATIONAL JOURNAL OF ACADEMIC RESEARCH IN BUSINESS AND SOCIAL SCIENCES

Vol. 10, No. 3, March, 2020, E-ISSN: 2222-6990 (C) 2020 HRMARS

leadership knowledge, leader encouragement and visionary leadership) are related to an increase or decrease in school sustainability. This implies that modern day leadership and school sustainability move in the same direction.

\section{Regression Results}

The general objective of this study was to assess whether school sustainability can be influenced by modern day leadership, hence the need to investigate the existence of a causal relationship between the study variables. This was done by running a regression analysis to ascertain whether modern day leadership constructs cause variations in school sustainability. The results are summarized in Table 4.

Table 4. Regression model summary coefficients

\begin{tabular}{|c|c|c|c|c|c|c|c|}
\hline \multicolumn{8}{|c|}{ Coefficients $^{\mathrm{a}}$} \\
\hline \multirow[t]{2}{*}{ Model } & \multicolumn{2}{|c|}{$\begin{array}{l}\text { Unstandardized } \\
\text { Coefficients }\end{array}$} & \multirow{2}{*}{$\begin{array}{c}\begin{array}{c}\text { Standardized } \\
\text { Coefficients }\end{array} \\
\text { Beta }\end{array}$} & \multirow[t]{2}{*}{$T$} & \multirow[t]{2}{*}{ Sig. } & \multicolumn{2}{|c|}{$\begin{array}{c}\text { Collinearity } \\
\text { Statistics }\end{array}$} \\
\hline & B & $\begin{array}{l}\text { Std. } \\
\text { Error }\end{array}$ & & & & Tolerance & VIF \\
\hline (Constant) & .189 & .220 & & 5.166 & .000 & & \\
\hline Long-term vision & .426 & .077 & .235 & 1.470 & .150 & .726 & 1.377 \\
\hline Knowledge & .246 & .067 & .472 & 2.768 & .011 & .691 & 1.447 \\
\hline Enthusiasm & .614 & .081 & .637 & 2.104 & .000 & .926 & 1.080 \\
\hline Encouragement & .537 & .062 & .458 & 2.209 & .002 & .895 & 1.336 \\
\hline & \multicolumn{7}{|c|}{ R Square $=.596$, Adjusted R Square $=.562, F=2.510$, sig. $=.003$} \\
\hline
\end{tabular}

Multiple regression analysis was used to test if modern day leadership constructs predicted school sustainability. The results indicate a model fit of $56.2 \%\left(R^{2}=.562\right)$. This means that $56.2 \%$ of school sustainability is explained by modern day leadership. This is a very substantial contribution which must not be ignored. The results further indicate that the model significantly and linearly predicted the $56.2 \%$ of school sustainability $(F=2.510, p=.003)$. These findings are in agreement with Forrest (2011) who contents that people today envision leadership as a necessary part of business and with global markets and the ever changing wants and needs of consumers, the old methods of leadership are no longer sufficient. Furthermore, the findings corroborate with Naluwemba et al. (2015), who found that school heads' leadership traits have a significant and positive impact on learners' academic Attainment in particular and the school as whole. 
INTERNATIONAL JOURNAL OF ACADEMIC RESEARCH IN BUSINESS AND SOCIAL SCIENCES

Vol. 10, No. 3, March, 2020, E-ISSN: 2222-6990 @ 2020 HRMARS

Test of Hypotheses

Table 5. Summary of the results of hypotheses testing

\begin{tabular}{|l|l|l|}
\hline Research Hypotheses & Decision \\
\hline H1 & $\begin{array}{l}\text { Visionary leadership positively influences sustainability of } \\
\text { private secondary schools. }\end{array}$ & Supported \\
\hline H2 & $\begin{array}{l}\text { Leadership knowledge is positively related to sustainability } \\
\text { of private secondary schools. }\end{array}$ & Supported \\
\hline H3 & $\begin{array}{l}\text { Leader enthusiasm significantly affects sustainability of } \\
\text { private secondary schools. }\end{array}$ & Supported \\
\hline H4 & $\begin{array}{l}\text { Leader encouragement has a positive and significant } \\
\text { relationship with sustainability of private secondary } \\
\text { schools. }\end{array}$ & Supported \\
\hline
\end{tabular}

Source: Analysis results

\section{Conclusion}

This study sought to establish whether sustainability of private secondary schools is influenced by modern day leadership. Results have shown that modern day leadership practices have a positive effect on sustainability of private secondary schools. Specifically, the findings have indicated that leader enthusiasm as a construct of modern day leadership is a significant predictor of private secondary schools sustainability. To sum it up, $56.2 \%$ of school sustainability is predicted or explained by modern day leadership. This implies that modern day leadership is an important antecedent of achieving school sustainability. It is therefore vivacious that private secondary school investors and leaders should apply modern leadership tools like long-term vision, Knowledge, Enthusiasm and Encouragement so as sustain their schools. We therefore strongly recommend that school leaders should be trained on modern day leadership skills or tools in order to acquire the necessary competences that will enhance school survival and sustainability.

\section{Theoretical and Practical Contributions}

Theoretically, the study adds on to the knowledge of modern day leadership practices such as visionary leadership, skills and experiences, enthusiasm and follower motivation. Scholars and academicians will also find this study an invaluable source of reference material for future studies in the area as well as for discussions in the field of modern day leadership. Practically, the study will be invaluable to private secondary school leaders who can use the findings of the study to improve school sustainability. In the same vain, this study provides important insights that allow government technocrats such as the Municipal Education Office to better understand private secondary school leadership and sustainability.

\section{Limitations of the Study and Areas for Further Research}

Although the study provides some interesting findings and makes important contributions to modern day leadership literature, several potential limitations are worth noting. A cross-sectional approach was undertaken. This approach prohibits studying the sequential aspects of contractor performance. Secondly, the data collection instrument that was used in this study was a standardardized questionnaire and quantitative in nature. The use of qualitative studies with in-depth interviews 
INTERNATIONAL JOURNAL OF ACADEMIC RESEARCH IN BUSINESS AND SOCIAL SCIENCES

Vol. 10, No. 3, March, 2020, E-ISSN: 2222-6990 (C) 2020 HRMARS

could have given more insights. Lastly, this study examined modern day leadership from the school administrators view point. Future research on modern day leadership from students and class room teachers' point of view is called for.

\section{References}

Ackoff, R. L. (1989). From data to wisdom. Journal of Applies Systems Analysis, 16, 3-9

Akpala, A. (1982). Industrial relations model for developing countries: The case of Nigeria. Review of African Political Economy

Alavi, M., Leidner, D. E. (2001). Knowledge management and knowledge management systems: conceptual foundations and research issues. MIS Quarterly 25 (1), 107-136

Amin, M. E. (2005). Social Science Research: Concepts, Methodology and Analysis. Kampala: Blackwell Publishing.

Bates, M. J. (2005). Information and knowledge: an evolutionary framework for information science. Information Research, 10 (4) (paper 239).

Bennis, W. (1990). Managing the Dream: Leadership in the 21st Century, Training: The Magazine of Human Resource Development, 27(5): 44-46.

Bulut, A. (2015). An Analysis of the Organizational Happiness Perceptions of Secondary School Teachers. Ph.D. Thesis, Gaziantep University, Gaziantep, Turkey, unpublished.

Carns, M. R., \& Carns, A. W. (2006). A review of the professional literature concerning the consistency of the definition and application of Adlerian encouragement. In S. Slavik \& J. Carlson (Eds.), Readings in the theory of individual psychology (pp. 277-293). New York, NY: Taylor \& Francis.

Davenport, T. H., Prusak, L. (1998). Working knowledge: how organizations manage what they know. Harvard Business School Press, Boston, Massachusetts

Dinkmeyer, D., \& Eckstein, D. (1996). Leadership by encouragement. Boca Raton, FL: CRC Press.

Fleishman, E. A., Mumford, M. D., Zaccaro, S. J., Levin, K. Y., Korotkin, A. L., Hein, M. B. (1991). Taxonomic efforts in the description of leader behavior: asynthesis and functional interpretation. The Leadership Quarterly 2 (4), 245-287

Hall-Kenyon, K. M., Bullough, R. V., MacKay, K. L., Marshall, E. E. (2014). Preschool teacher wellbeing: A review of the literature. Early Child. Educ. 42, 153-162.

Hwang, K. O., Ottenbacher, A. J., Lucke, J. F., Etchegaray, J. M., Graham, A. L., Thomas, E. J., \& Bernstam, E. V. (2011). Measuring social support for weight loss in an internet weight loss community. Journal of Health Communication, 16, 198-211. doi:10.1080/10810730.2010.535106

Jiménez, P., Winkler, B., Bregenzer, A. (2017). Developing sustainable workplaces with leadership: Feedback about organizational working conditions to support leaders in health-promoting behavior. Sustainability.

Kouzes, J. M., and Posner, B. Z. (1987). The Leadership Challenge: How to Get Extraordinary Things Done in Organizations, San Francisco: Jossey-Bass.

KPMG. (2000). Knowledge management research report. KPMG Consulting,

Lakshman, C. (2005). Top executive knowledge leadership: managing knowledge to lead change at General Electric. Journal of Change Management, 5 (4), 429-446 
INTERNATIONAL JOURNAL OF ACADEMIC RESEARCH IN BUSINESS AND SOCIAL SCIENCES

Vol. 10, No. 3, March, 2020, E-ISSN: 2222-6990 (C) 2020 HRMARS

Lakshman, C. (2007). Organizational knowledge leadership: a grounded theory approach. Leadership and Organization Development Journal 28 (1), 51-75

Lawal, A. (I 993) Management in focus. LLP, Annapolis, Maryland.

Lumby, J. (2013). Distributed leadership: The uses and abuses of power. Educ. Manag. Adm. Leadersh. J, 41, 581-597.

Nikelly, A., \& Dinkmeyer, D. (1971). Techniques for behavior change: Applications of Adlerian theory. Springfield, IL: Charles C Thomas.

Nwanchuckwu, C. C. (1988) Personnel administration in Nigeria, University of port-harcourt press, Nigeria.

Pearce, Terry. (1995). Leading Out Loud: The Authentic Speaker, the Credible Speaker. Jossey-Bass Publishers, San Francisco, CA.

Rainey, D., \& Rainey, B. (2010). Building up your spouse. Little Rock, AR: Family Life.

Sabherwal, R., Becerra-Fernandez, I. (2003). An empirical study of the effect of knowledge management processes at individual, group, and organizational levels. Decision Sciences 34 (2), 225-260

Sashkin, M. (1988) 'The Visionary Leader', in J.A. Conger, and R.N. Kanungo (Eds.), CharismaticLeadership: The Elusive Factor in Organizational Effectiveness, San Francisco: Jossey-Bass, pp. 122160.

Sekaran, U. \& Bougie, R. (2010). Research Methods for Business: A Skill Building Approach. 5th Edition

Sikula, A. F. (1996) Personnel administration and human resources. Oluseyi Press Ibadan, Nigeria. Smith, L. M. (2017). Study of Teacher Engagement in Four Dimensions of Distributed Leadership in One School District in Georgi. Ph.D. Thesis, Georgia Southern University, Statesboro, GA, USA.

Sweeney, T. J. (2009). Adlerian counseling and psychotherapy: A practitioner's approach. New York, NY.

Ubeku, A. A. (1975) Personnel management in Nigeria: Ethiope Publishing Corporation, Benin City.

Vroom, V. H., Jago, A. G. (1988). The new leadership: managing participation in organizations. Prentice-Hall, Englewood Cliffs, New Jersey.

Walzer, N. (2016). Rural Community Economic Development. Praeger Publishers, New York, NY. 